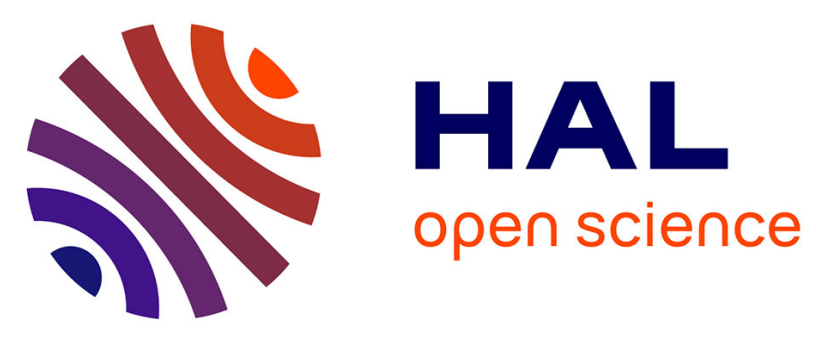

\title{
Nanostructured Y 2 O 3 ceramics elaborated by Spark Plasma Sintering of nanopowder synthesized by PEG assisted combustion method: The influence of precursor morphological characteristics
}

\author{
Radenka Krsmanović Whiffen, Damien Bregiroux, Bruno Viana
}

\section{To cite this version:}

Radenka Krsmanović Whiffen, Damien Bregiroux, Bruno Viana. Nanostructured Y 2 O 3 ceramics elaborated by Spark Plasma Sintering of nanopowder synthesized by PEG assisted combustion method: The influence of precursor morphological characteristics. Ceramics International, 2017, 43 (17), pp.15834-15841. 10.1016/j.ceramint.2017.08.153 . hal-01653399

\section{HAL Id: hal-01653399 \\ https: / hal.sorbonne-universite.fr/hal-01653399}

Submitted on 1 Dec 2017

HAL is a multi-disciplinary open access archive for the deposit and dissemination of scientific research documents, whether they are published or not. The documents may come from teaching and research institutions in France or abroad, or from public or private research centers.
L'archive ouverte pluridisciplinaire HAL, est destinée au dépôt et à la diffusion de documents scientifiques de niveau recherche, publiés ou non, émanant des établissements d'enseignement et de recherche français ou étrangers, des laboratoires publics ou privés. 


\section{Nanostructured $\mathrm{Y}_{2} \mathrm{O}_{3}$ ceramics elaborated by Spark Plasma Sintering of} nanopowder synthesized by PEG assisted combustion method: the influence of precursor morphological characteristics

5 Radenka M. Krsmanović Whiffen ${ }^{\mathrm{a}, \mathrm{c}}$, Damien Bregiroux ${ }^{\mathrm{b}, *}$, Bruno Viana $^{\mathrm{c}}$

6 a Vinča Institute of Nuclear Sciences, University of Belgrade, P.O. Box 522, 11001

7 Belgrade, Serbia

$8{ }^{\mathrm{b}}$ Sorbonne Universités, UPMC Univ Paris 06, CNRS, Collège de France, Laboratoire

9 de Chimie de la Matière Condensée de Paris, 4 place Jussieu, 75005 Paris, France

$10{ }^{\mathrm{c}}$ Institut de Recherche de Chimie Paris (IRCP), CNRS - Chimie Paris Tech - Paris

11 Sciences et Lettres PSL UMR8247, 11 rue Pierre et Marie Curie, 75005 Paris, France

13 * Corresponding author. Tel.: + 33144275679

14 E-mail address: damien.bregiroux@upmc.fr (D. Bregiroux)

\section{Abstract}

17 Dense yttria ceramics were prepared by Spark Plasma Sintering of a nanopowder synthesized using a PEG assisted combustion method. Densification occurs between $800^{\circ} \mathrm{C}$ and $900^{\circ} \mathrm{C}$ without any additive. This corresponds to one of the lowest sintering

20 temperature found in the literature for $\mathrm{Y}_{2} \mathrm{O}_{3}$. Because of a significant release of organic 21 species, the $\mathrm{Y}_{2} \mathrm{O}_{3}$ precursors obtained by this synthesis route contains macropores that 22 have a negative impact on the final microstructure. We show that the emergence of 23 these macropores can be minimized by decreasing the annealing temperature used for 24 the precursor powder (in a temperature range of $300^{\circ} \mathrm{C}-650^{\circ} \mathrm{C}$ ) as opposed to the usual 
$1800^{\circ} \mathrm{C}$. Finally, a precursor annealed at $650^{\circ} \mathrm{C}$ allows us to obtain fully dense ceramics,

2 with a very fine and homogeneous microstructure (and a grain size around $300 \mathrm{~nm}$ ).

3 Vickers microhardness and fracture toughness were measured and discussed in relation

4 to the microstructure of the ceramics.

5

\section{Keywords}

$7 \quad$ A. Grain growth; Sintering

8 B. Electron microscopy

9 D. $\mathrm{Y}_{2} \mathrm{O}_{3}$

11 Highlights

12 - Full densification at very low temperature (a very reactive $\mathrm{Y}_{2} \mathrm{O}_{3}$ nanopowder)

13 - Ceramics of fine grain size (around $300 \mathrm{~nm}$ ) with good mechanical properties

14 - Agglomerated starting nanopowders lead to opaque ceramics

\section{1. Introduction}

17 Yttria, $\mathrm{Y}_{2} \mathrm{O}_{3}$, is a cubic structure bixbyite oxide and a very promising material for

18 optical devices and high temperature refractories due to its wide optical transmission

19 range $(0.2-8 \mu \mathrm{m})$, high corrosion resistivity, thermal stability, and its high melting point

20 of around $2430{ }^{\circ} \mathrm{C}$ [1]. For optical applications, yttria is preferably fabricated in the

21 form of transparent ceramic as, due to its refractory characteristics, it is hard to obtain

22 single crystals [2]. Although the first transparent yttria ceramic was reported almost 50

23 years ago [3] it has attracted and continues to attract numerous researchers, who explore

24 the various means of its production. The opportunity to create such optically transparent 
1 ceramics relies on the control of two key parameters: residual porosity $\left(10^{-2}\right.$ to $10^{-3}$ vol.

$2 \%$ or less) and grain boundaries purity. For these reasons the sintering of polycrystalline

3 ceramics for optical applications typically involves long treatments at high temperatures

4 (usually $70-80 \%$ of the melting point) generally using hot pressing (HP) [4], hot-

5 isostatic pressing (HIP) [5-7], or vacuum sintering [8,9], with the aim of obtaining a

6 very dense final bulk material. Nevertheless, yttria ceramics prepared in this way

7 generally have large grains, in the range of hundreds of microns, leading to low

8 mechanical strength which in turn limits opportunities for their practical application.

9 In recent years, the idea of making nanostructured ceramics, i.e. ceramics with sub-

10 micron sized grains, starting from appropriate ultrafine precursor nanopowders, has

11 been of interest to numerous researchers. The main strategy is to modify standard

12 fabrication methods and to study the effects of starting powder characteristics on the

13 sintering and microstructure of the ceramics [10-13]. The main benefit of using

14 nanostructured ceramics lies in the fact that their mechanical properties, such as

15 hardness and fracture toughness, are generally improved when grain size is maintained

16 at a nanometric scale [14]. The requirement of achieving almost total densification with

17 an extremely small grain size has led towards the use of non-conventional sintering

18 methods, generally combining low sintering temperatures and high pressures. The Spark

19 Plasma Sintering (SPS) method is one of the most commonly investigated method so far

20 [15-23]. In parallel, many efforts have been made over recent decades in terms of the

21 development of new synthesis routes for $\mathrm{Y}_{2} \mathrm{O}_{3}$ nanopowders in order to obtain a powder

22 with better sintering behaviour [24-25]. In our previous studies of bixbyite oxides in the

23 form of highly crystalline nanopowders we proposed and used extensively a

24 polyethylene glycol (PEG) - assisted combustion method known as the polymer 
1 complex solution (PCS) [26-28]. The simple equipment required and low energy

2 consumption levels makes this method attractive for the fabrication of diverse oxide

3 nanomaterials with excellent qualities for ceramic fabrication [29-30] including the

4 potential extension of this approach to industrial scale production. The goal of this work

5 was to evaluate the Spark Plasma Sintering behaviour of $\mathrm{Y}_{2} \mathrm{O}_{3}$ nanopowders

6 synthesized using a PEG assisted combustion method. This work was performed with a

7 focus on the influence of precursor agglomeration and nanoparticles size that are

8 directly related to the temperature used in the post-synthesis thermal treatment of the

$9 \quad \mathrm{Y}_{2} \mathrm{O}_{3}$ nanopowders. Densification and final microstructure were examined in relation to

10 the synthesis and sintering conditions. The obtained results were compared with those

11 found in the literature. Conclusions were drawn concerning the potential use of the PEG

12 assisted combustion method for the elaboration of $\mathrm{Y}_{2} \mathrm{O}_{3}$ ceramics for possible optical

13 and mechanical applications.

\section{2. Experimental}

16 Several tens of grams of $\mathrm{Y}_{2} \mathrm{O}_{3}$ nanopowder were synthesized using the PCS method

17 [26-28]. Aqueous solutions of stoichiometric quantities of yttrium nitrate were prepared

18 by dissolving appropriate quantities of $\mathrm{Y}_{2} \mathrm{O}_{3}$ (Alfa Aesar, 99.9\%) in a hot nitric acid

19 solution. All the chemicals were of the highest purity available and were used without

20 further purification.

21 In the prepared solutions, PEG 200 (Alfa Aesar) was added in a 1:1 mass ratio to the

22 oxide used. After stirring for several hours at $80^{\circ} \mathrm{C}$, this metal-PEG solution

23 transformed into a metal-PEG resin-like solid complex that was further combusted at

$24800^{\circ} \mathrm{C}$ in air, and then annealed at $800^{\circ} \mathrm{C}$ in air for 2 hours, resulting in a fine, white- 
1 coloured powder (sample $800^{\circ} \mathrm{C}-2 \mathrm{~h}$ ). This powder was used for the first part of our

2 experiment. For comparison, sintering tests were also performed on commercial $\mathrm{Y}_{2} \mathrm{O}_{3}$

3 powder (Alfa Aesar). For the second part of our experiment, where we wanted to

4 explore the influence of different nanoparticle size and powder agglomeration, a new

5 batch of $\mathrm{Y}_{2} \mathrm{O}_{3}$ powders was produced at lower annealing temperatures. We decided to

6 change the end part of the PCS procedure by decreasing both the temperature used for

7 combustion and for the final calcination. For the new batch of $\mathrm{Y}_{2} \mathrm{O}_{3}$ nanopowders, the

8 metal- PEG complex was combusted at only $350^{\circ} \mathrm{C}$ in air, and then calcinated at $300^{\circ} \mathrm{C}$

9 for 2 hours, resulting in a fine black powder. With further calcination at temperatures

10 lower than $800^{\circ} \mathrm{C}(400,500,550$, and 650$)$ for 2 hours we were able to tune the

11 crystallinity and particle size of $\mathrm{Y}_{2} \mathrm{O}_{3}$ nanopowder and get a white powder. One sample

12 was annealed for 10 hours at $450^{\circ} \mathrm{C}$.

13 The X-ray diffraction measurements of the $\mathrm{Y}_{2} \mathrm{O}_{3}$ nanopowder were obtained at room

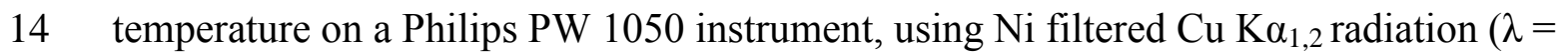

$151.5418 \AA$ ), in a $2 \theta$ range from $10^{\circ}$ to $120^{\circ}$ (with a step size of $0.02^{\circ}$ and a counting time

16 of $12 \mathrm{~s}$ per step). The X-ray diffraction measurements of the second set of powders,

17 with additional thermal treatments, were obtained at room temperature, on a Bruker D8,

18 using $\mathrm{Ni}$ filtered $\mathrm{Cu} \mathrm{K} \alpha_{1,2}$ radiation $(\lambda=1.5418 \AA)$, in a $2 \theta$ range from $15^{\circ}$ to $70^{\circ}$.

19 Thermal stability and possible phase transitions were studied using a Setaram DTA-TG

20 instrument. The $\mathrm{Y}_{2} \mathrm{O}_{3}$ gel sample (i.e. the metal-PEG resin-like solid complex), with a

21 mass of $32.8 \mathrm{mg}$, was put into a Pt crucible, heated up to $800^{\circ} \mathrm{C}$ and then cooled under an argon atmosphere at a rate of $5^{\circ} \mathrm{C} \mathrm{min}^{-1}$. The specific surface area of the ground

23 powders was measured according to the BET method, using $\mathrm{N}_{2}$ as an adsorbate

24 (Bellsorp, Bell, Japan). The samples were degassed for 12 hours at $150^{\circ} \mathrm{C}$ prior to the 
1 analysis. The microstructure of the $\mathrm{Y}_{2} \mathrm{O}_{3}$ nanopowders, subjected to different thermal

2 treatments, was analyzed by transmission electron microscopy (TEM FEI G2 operating

3 at $120 \mathrm{kV}$ ) in bright field. For the TEM observations, a suspension of particles in

4 ethanol was ultrasonicated for 20 minutes and dropped onto a holey carbon copper grid.

5 Sintering experiments were performed under a 0.1 mbar vacuum using the SPS

6 technique (Dr. Sinter 515S Syntex machine). The $\mathrm{Y}_{2} \mathrm{O}_{3}$ powder was filled into a

7 graphite die with an inner diameter of $8 \mathrm{~mm}$. Approximately 0.25 grams of the

8 precursor powder was needed for a ceramic disc of a thickness of $2 \mathrm{~mm}$. The

9 temperature was monitored by a thermocouple, ranging from room temperature to the

10 sintering temperature. Sample shrinkage was followed by the displacement of the lower

11 punch. The heating rate and cooling rate were set to $100{ }^{\circ} \mathrm{C} \cdot \mathrm{min}^{-1}$ and $50{ }^{\circ} \mathrm{C} \cdot \mathrm{min}^{-1}$,

12 respectively. Pressure was applied gradually from room temperature to $400{ }^{\circ} \mathrm{C}$ and

13 maintained at its maximum value until the beginning of the cooling step. The pressure

14 was then removed over the course of 10 minutes. The sintered sample was then

15 annealed under flowing air at $700{ }^{\circ} \mathrm{C}$ for 10 hours in order to remove carbon

16 contamination from the graphite die and the oxygen vacancies generated by the

17 reducing environment during sintering.

18 The microstructures of the ceramic samples were observed on fractures using a SEM

19 (Hitachi S-3400N), working at an accelerating voltage of $20 \mathrm{kV}$. The surface of the

20 samples was coated with a thin layer of carbon prior to observation. The relative density

21 of the SPS sintered discs was measured by the Archimedes method in distilled water,

22 assuming that the theoretical density of $\mathrm{Y}_{2} \mathrm{O}_{3}$ was $5.03 \mathrm{~g} \mathrm{~cm}^{-3}$ [31]. Vickers

23 microhardness and fracture toughness were measured on polished ceramics using a 
1 microhardness tester (Bruck MHT 200). Microhardness $H v$ was determined using the

2 following equation:

$3 \quad H_{V}=k\left(\frac{P}{d^{2}}\right)$

4 where $P$ is the applied load $(500 \mathrm{~g}$, i.e. $4.903 \mathrm{~N}), k$ the shape factor $(0.1891)$ and $d$ the

5 indent diagonal $(\mathrm{mm})$.

6 The fracture toughness was calculated using the following equation [32]:

$$
\mathrm{K}_{\mathrm{IC}}=0.016\left(\frac{\mathrm{E}}{\mathrm{H}_{\mathrm{V}}}\right)^{\frac{1}{2}}\left(\frac{\mathrm{P}}{\mathrm{C}^{\frac{3}{2}}}\right)
$$

8 where $E$ is the Young's modulus of $\mathrm{Y}_{2} \mathrm{O}_{3}$ (179.8 GPa, according to [33]) and $C$ the

9 linear size of the radial crack.

10 All the final results represent the average of 20 indentation tests.

\section{3. Results and discussion}

\section{3.1. Precursors and $\mathrm{Y}_{2} \mathrm{O}_{3}$ powders characterization}

14 Figure 1 shows the morphology of the two yttria powders with which we started this

15 study. The commercial $\mathrm{Y}_{2} \mathrm{O}_{3}$ powder (Figure $1 \mathrm{a}$ and $\mathrm{b}$ ) consists of well crystallized

16 particles (confirmed by XRD) with a diameter in the range of $50-100 \mathrm{~nm}$. Those

17 particles are strongly agglomerated to form hard and dense agglomerates of $1-4 \mu \mathrm{m}$ in

18 size. The resulting specific surface area of this powder is indeed very low (around 1.1

$\left.19 \mathrm{~m}^{2} \cdot \mathrm{g}^{-1}\right)$ 

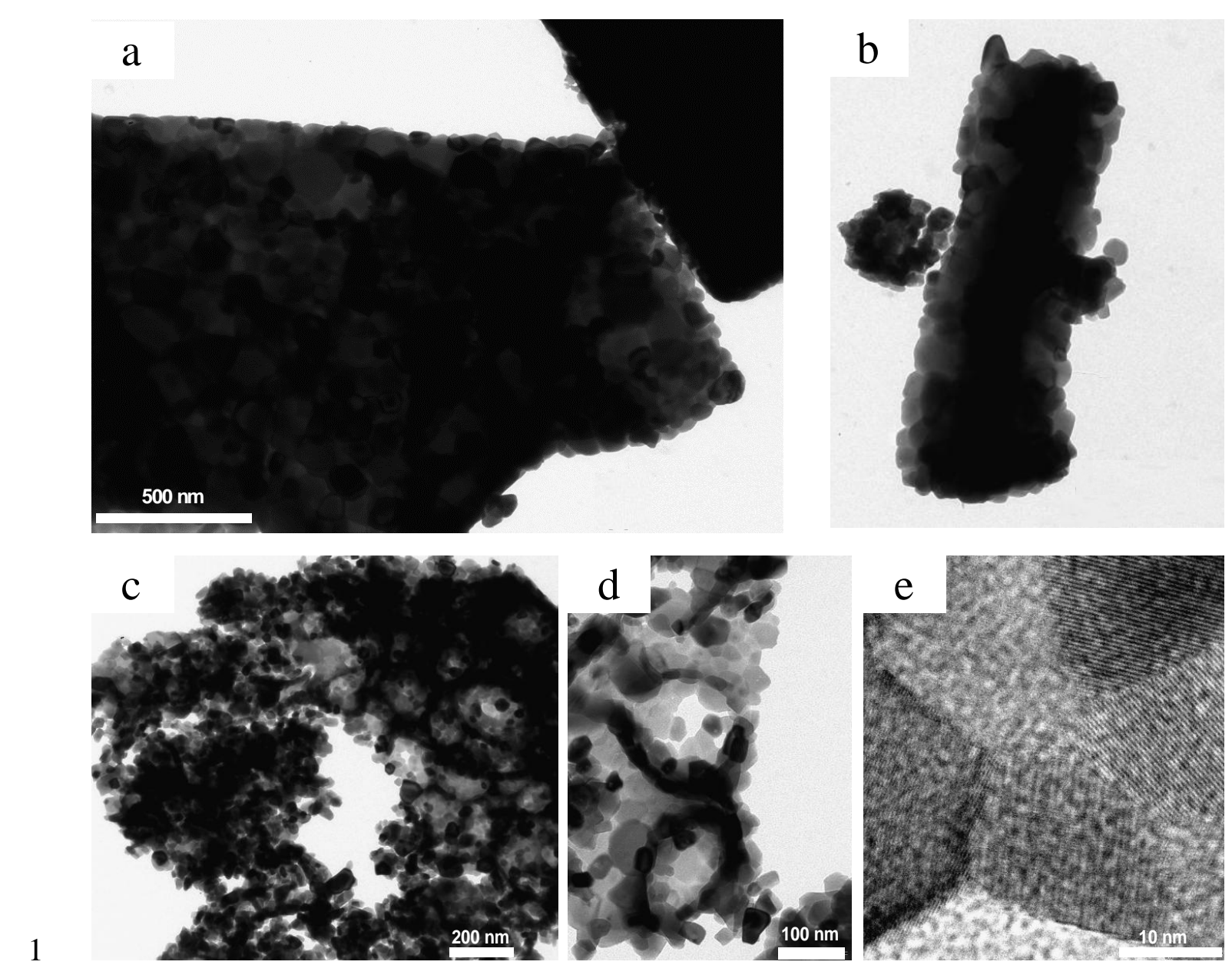

2 Figure 1. Morphology of the commercial ( $\mathrm{a}$ and $\mathrm{b}$ ) and PCS-produced (PEG Mw $=$

3 200) (c, d and e) yttria powder used in this study.

4

5 The synthesized $\mathrm{Y}_{2} \mathrm{O}_{3}$ powder exhibits a very different morphology. It consists of well

6 crystallized nanoparticles, clearly visible in Figure 1 (c, $d$ and e), with an average

7 diameter of $20-30 \mathrm{~nm}$. Those particles form loose agglomerates, $1-2 \mu \mathrm{m}$ in size,

8 containing holes which are $50-300 \mathrm{~nm}$ in diameter. The thermal behaviour of the

9 metal-PEG complex (the $\mathrm{Y}_{2} \mathrm{O}_{3}$ gel sample) under heating, up to $800^{\circ} \mathrm{C}$, and the ideal

10 temperature for its decomposition were determined by TG/DTA analysis (see Figure 2).

11 Most of the weight loss, around $65 \%$ of the initial weight, occurs between $100^{\circ} \mathrm{C}$ and

$12450^{\circ} \mathrm{C}$. This corresponds to water evaporation and the decomposition of all organic 
1 species. A slight weight loss also occurs at around $600^{\circ} \mathrm{C}$. This is probably due to the

2 decomposition of yttrium carbonate [30]. We noticed that the powders from the second

3 batch, when calcinated at temperatures below $500{ }^{\circ} \mathrm{C}$ are either black or grey, and

4 become white when calcinated beyond this temperature.

5

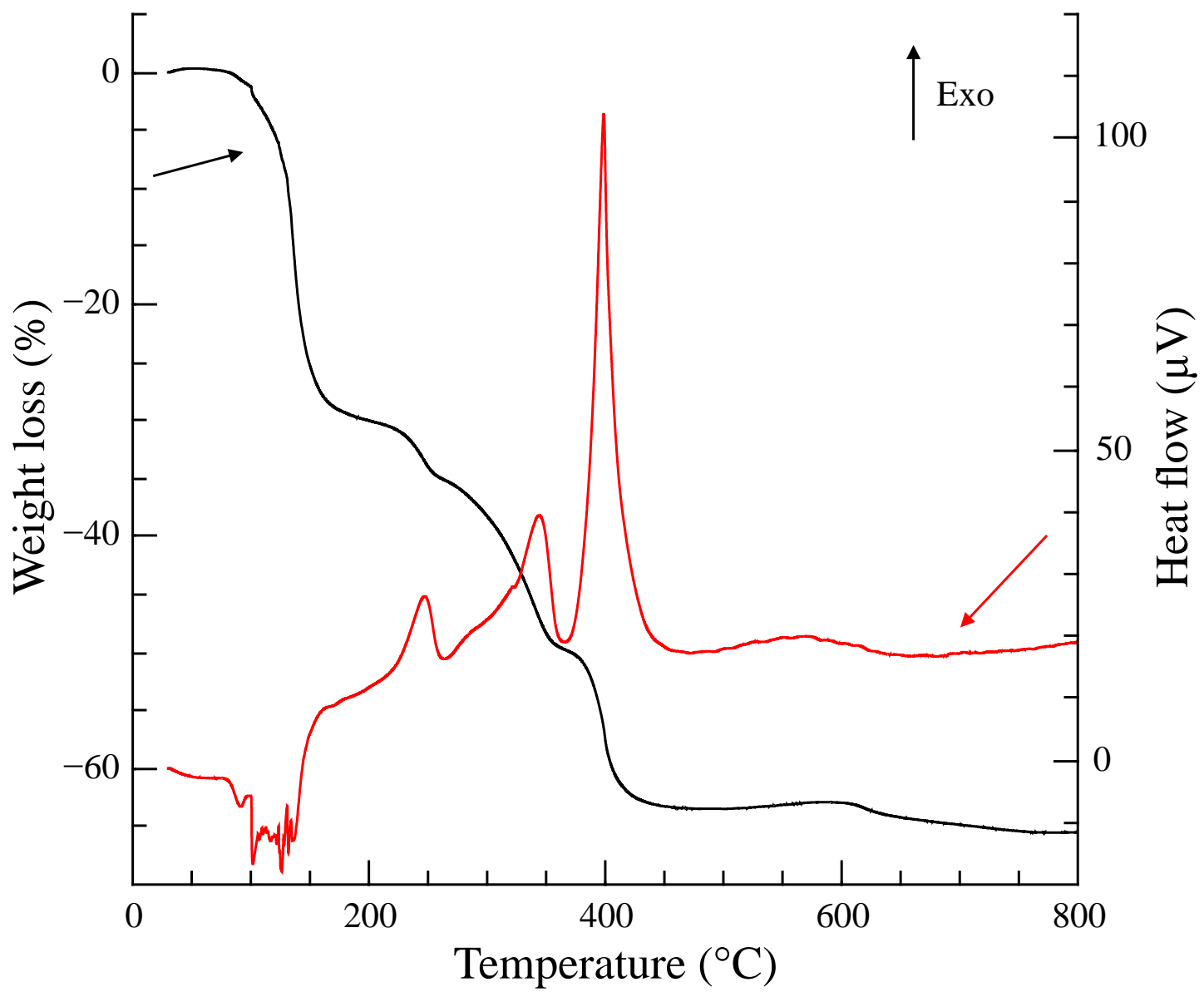

6

7 Figure 2. Thermal behaviour of the metal-PEG resin-like solid complex (the $\mathrm{Y}_{2} \mathrm{O}_{3}$ gel

8 sample).

9

10 The specific surface area (SSA) of lab-synthesized $\mathrm{Y}_{2} \mathrm{O}_{3}$ is much higher than that of the

11 commercial powder and is in the range of 22 to $25 \mathrm{~m}^{2} \cdot \mathrm{g}^{-1}$ depending on the post-

12 synthesis thermal treatments: the starting powder (i.e. the one annealed at $300^{\circ} \mathrm{C}$ ) 
1 exhibited a specific surface area of $25.4 \mathrm{~m}^{2} \cdot \mathrm{g}^{-1}$. As expected, the specific surface area

2 decreases with the increase in the annealing temperature from 300 to $800^{\circ} \mathrm{C}\left(25 \mathrm{~m}^{2} \cdot \mathrm{g}^{-1}\right.$

3 for $400^{\circ} \mathrm{C}, 24.8 \mathrm{~m}^{2} \cdot \mathrm{g}^{-1}$ for $500^{\circ} \mathrm{C}$ and $550^{\circ} \mathrm{C}$, and $21.8 \mathrm{~m}^{2} \cdot \mathrm{g}^{-1}$ for $800^{\circ} \mathrm{C}$; see Figure 3),

4 with a transient increase at $650^{\circ} \mathrm{C}\left(25.6 \mathrm{~m}^{2} \cdot \mathrm{g}^{-1}\right)$ due to the decomposition of the

5 carbonate species (see the TG plot in Figure 2). The sample annealed at $800^{\circ} \mathrm{C}$ was the

6 one produced using the standard PCS procedure (from the first batch).

7

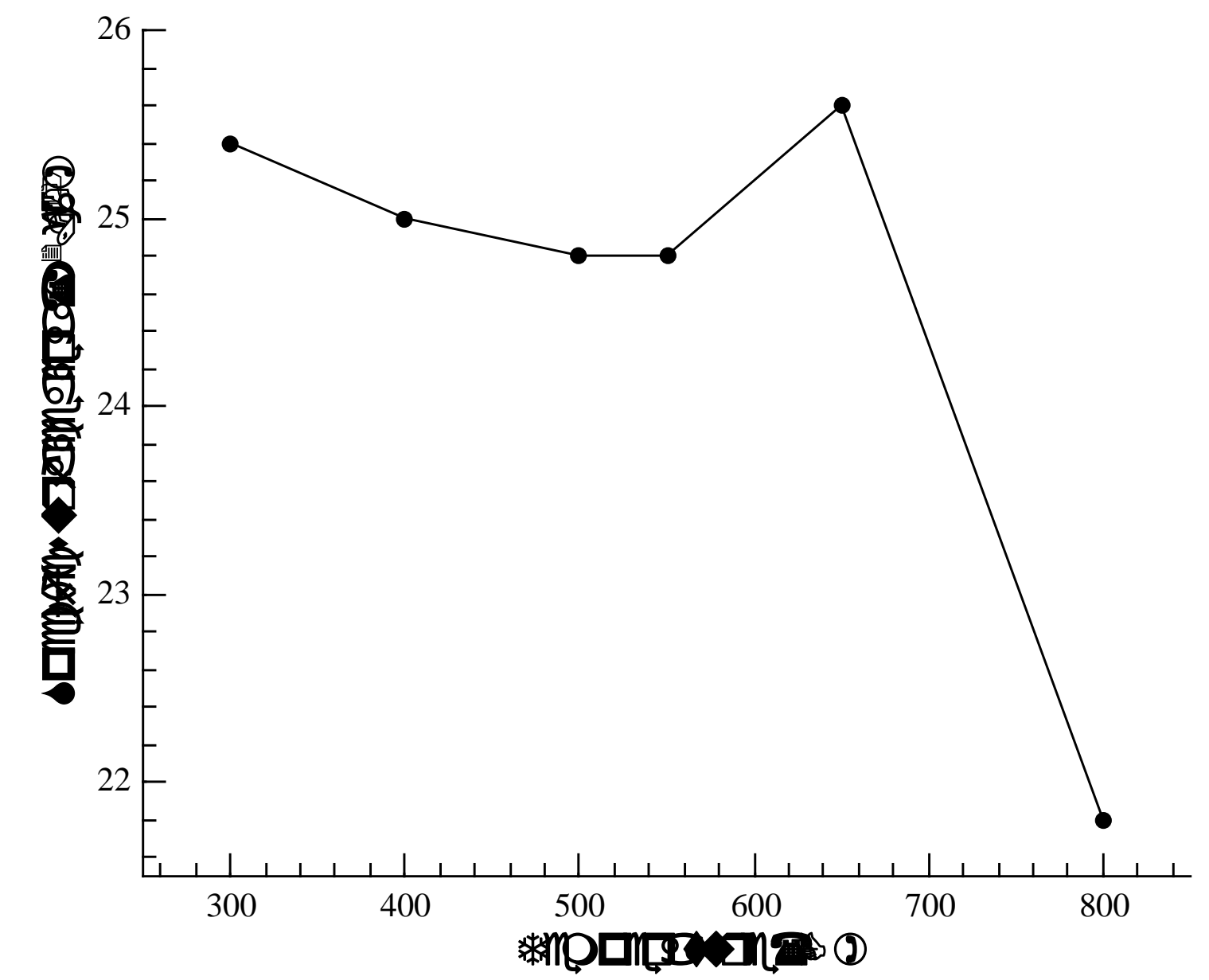

9 Figure 3. Specific surface area of the raw $\mathrm{Y}_{2} \mathrm{O}_{3}$ powders after annealing at different

10 temperatures and the PCS-standardly produced sample annealed at $800{ }^{\circ} \mathrm{C}$. 
1 XRD analyses revealed that the cubic form of $\mathrm{Y}_{2} \mathrm{O}_{3}\left(\mathrm{SG} I a-3 \mathrm{n}^{\circ} 206, a=10.6023 \AA\right.$ )

2 can be observed in the samples annealed at $300^{\circ} \mathrm{C}$ and above (see Figure 4). The XRD

3 peaks are broad and weak for sample annealed at $300^{\circ} \mathrm{C}$ and progressively become

4 sharper and more intense as both the temperature and annealing time increase. This can

5 be directly associated with the increase in nanoparticle size, as can be observed in

6 Figure 5. For sample annealed at $400^{\circ} \mathrm{C}$, the nanoparticle size is found to be as small as

$7 \quad 6 \mathrm{~nm}$. The particle size starts to increase rapidly when the annealing temperature is

8 greater than $650^{\circ} \mathrm{C}$. For the $800^{\circ} \mathrm{C}$ treatment, the nanoparticles have an average size of

9 around $25 \mathrm{~nm}$.

10

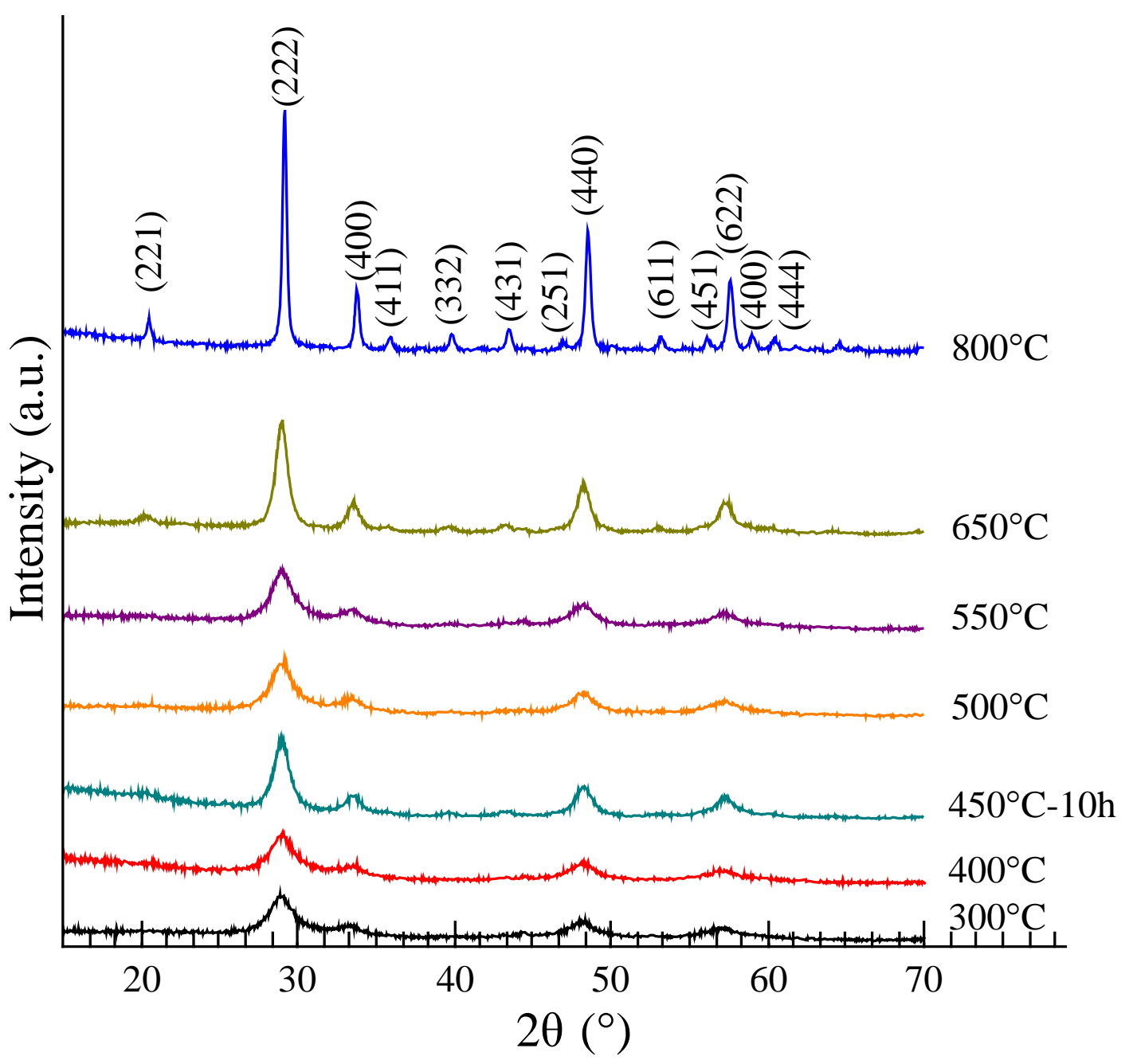


1 Figure 4. XRD patterns of the raw powders after different thermal treatment

2 temperatures vs. the PCS-standard sample annealed at $800{ }^{\circ} \mathrm{C}$.

3

4

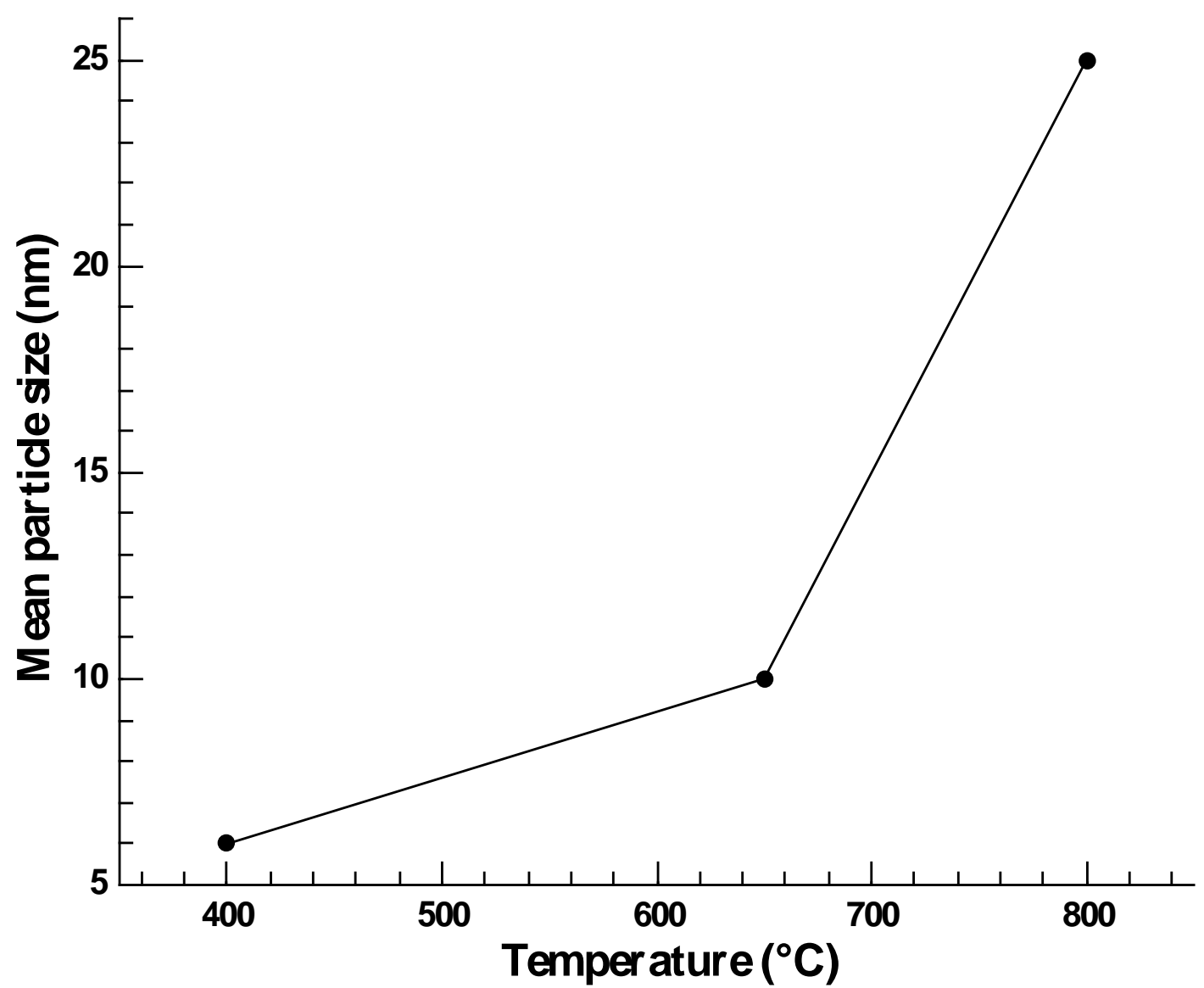

5

6 Figure 5. Mean nanoparticle size as a function of the annealing temperature, as

7 estimated from TEM pictures.

8

9 Examples of different powder morphologies are shown in Figure 6. We can clearly see

10 that macroporosity is present in the samples annealed at $400^{\circ} \mathrm{C}$ and at higher

11 temperatures, due to the elimination of organic species during annealing. No conditions

12 have so far been found for the PCS production of nanopowders without such 
1 macroporosity. The size of the macropores is the same regardless of the annealing

2 temperature; however the nanoparticles seems to have weaker grain boundaries when

3 the annealing is performed at a lower temperature. We expected that for the studied

4 conditions, the macropores (in the range of 20-200 nm) could be broken more easily

5 when pressure was applied during Spark Plasma Sintering.

6
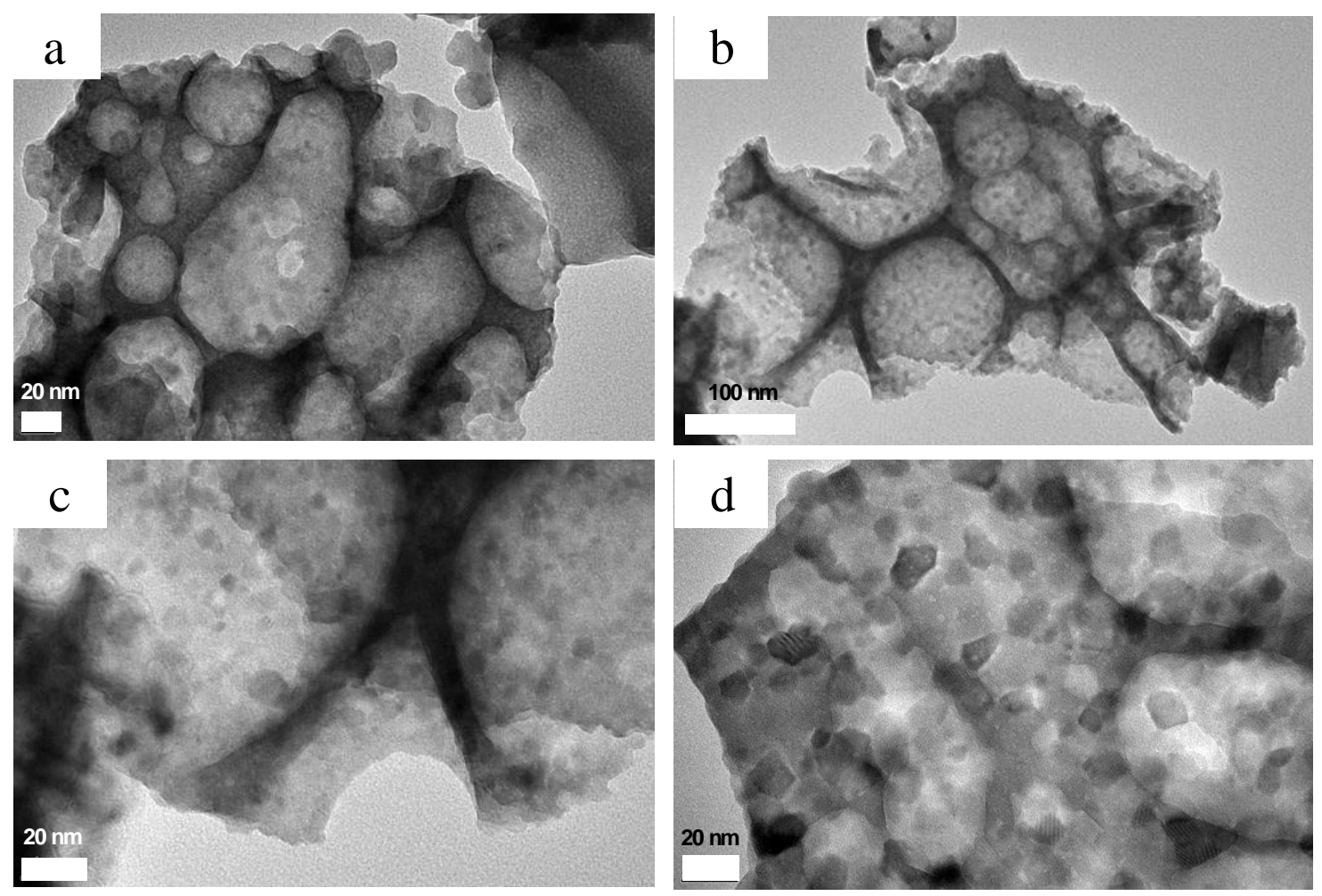

8 Figure 6. TEM pictures of $\mathrm{Y}_{2} \mathrm{O}_{3}$ powders after annealing at $400^{\circ} \mathrm{C}(\mathrm{a}), 450^{\circ} \mathrm{C}-10$ hours

$9 \quad(\mathrm{~b}$ and $\mathrm{c})$ and $650^{\circ} \mathrm{C}(\mathrm{d})$.

12 3.2. Spark Plasma Sintering and the characterization of ceramic samples

13 The synthesized powders were sintered by using the Spark Plasma Sintering technique.

14 Figure 7 depicts the densification behaviour of the $\mathrm{Y}_{2} \mathrm{O}_{3}$ nanopowder, PCS- synthesized 
1 at $800^{\circ} \mathrm{C}$, when sintered under a uniaxial pressure of $50 \mathrm{MPa}$ and $100 \mathrm{MPa}$. Linear

2 shrinkage, plotted in Figure 7 in arbitrary units, includes the Thermal Expansion

3 contribution of the graphite tool. For this reason, we removed the scale, since punch

4 displacement also depends on the amount of powder and the extent of its pre-

5 compaction.

6

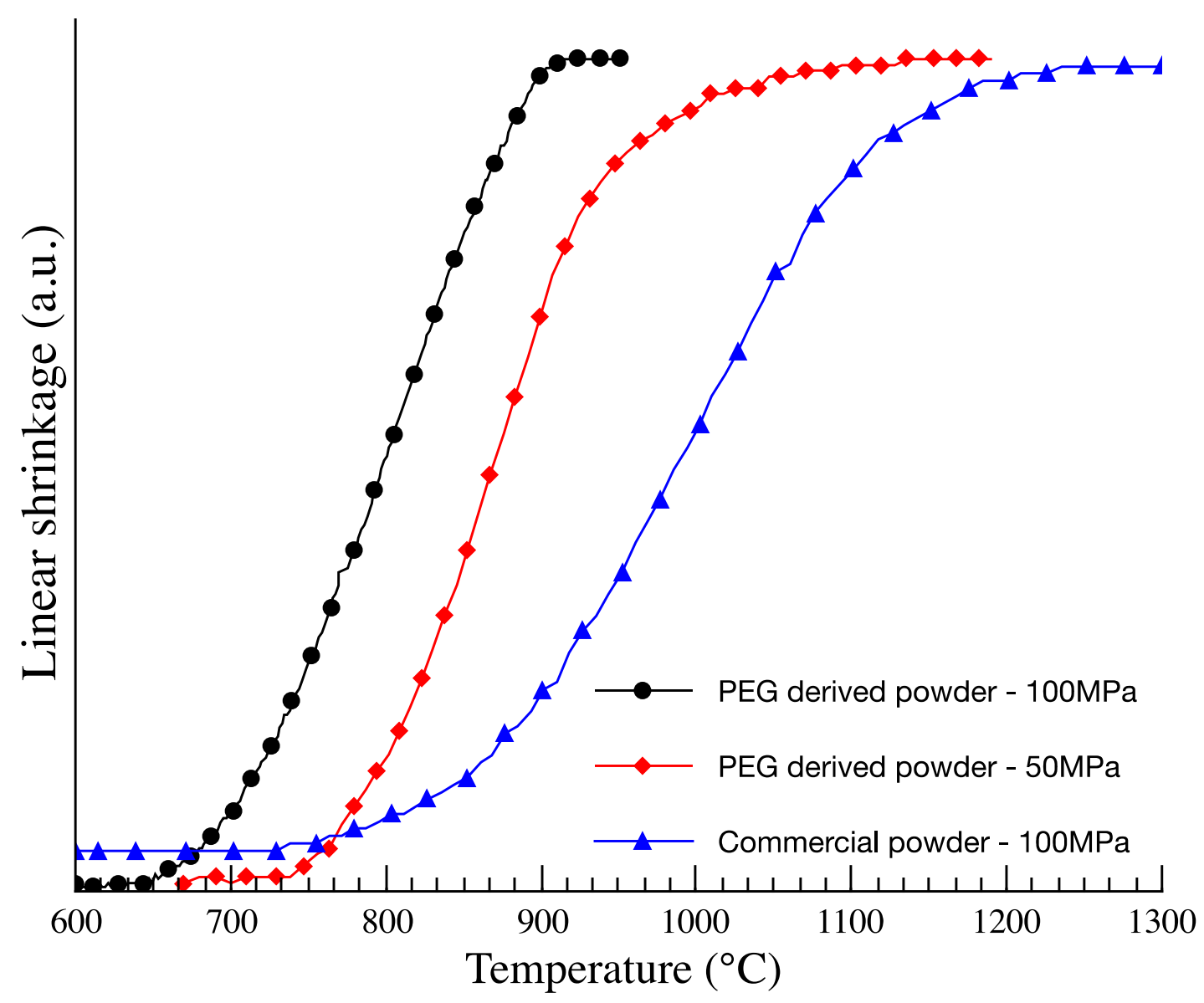

8 Figure 7. SPS linear shrinkage for the PEG derived $\mathrm{Y}_{2} \mathrm{O}_{3}$ samples sintered under 50

$9 \mathrm{MPa}$ (red lozenges) and $100 \mathrm{MPa}$ (black circles) uniaxial pressures and the commercial 10 powder sintered under $100 \mathrm{MPa}$ (blue triangles). 
1 Sintering under $100 \mathrm{MPa}$ instead of $50 \mathrm{MPa}$ lowers the densification temperature by

$280^{\circ} \mathrm{C}$. In addition, at high temperatures, the end of the densification curve is sharper for

3 sintering under $100 \mathrm{MPa}$. Irom et al. recently found that applying high pressure during

4 Spark Plasma Sintering led to a finer microstructure and consequently increased levels

5 of hardness and fracture toughness [35]. As a result, all the subsequent SPS experiments

6 were performed under a uniaxial pressure of $100 \mathrm{MPa}$.

7 Our results highlighted that, for PEG-derived powder, under an applied pressure of 100

$8 \mathrm{MPa}$, shrinkage begins at around $650^{\circ} \mathrm{C}$ and ends at $900^{\circ} \mathrm{C}$, which is similar to the

9 lowest sintering temperature found in the literature for the Spark Plasma Sintering of

10 undoped $\mathrm{Y}_{2} \mathrm{O}_{3}[15,21,22,36]$. For comparison, the experimental curve obtained from the

11 commercial powder under an applied pressure of $100 \mathrm{MPa}$ is presented, showing that

12 shrinkage starts at $725^{\circ} \mathrm{C}$ and is completed only at $1250^{\circ} \mathrm{C}$. Moreover, the densification

13 process is much faster for the PEG derived powder, since the temperature range for

14 densification is only $250^{\circ} \mathrm{C}$ (as opposed to $525^{\circ} \mathrm{C}$ for the commercial powder).

15 The final relative density of the produced ceramic discs was around $98 \%$ for the PEG

16 derived powder (at a sintering temperature of $1000^{\circ} \mathrm{C}$ ), and $99 \%$ for the commercial one

17 (at a sintering temperature of $1300^{\circ} \mathrm{C}$ ). Despite very good densification behaviour, the

18 ceramic samples made from the PEG derived powder were all opaque even when the

19 sintering temperature was set to higher values (with tests performed up to $1500^{\circ} \mathrm{C}$ ). By

20 contrast, the ceramics made from commercial powder were very slightly translucent

21 when produced at a sintering temperature of $1300^{\circ} \mathrm{C}$ or higher.

22 Figure 8 shows the mean grain size evolution, from $200 \mathrm{~nm}$ to $3 \mu \mathrm{m}$, with the respective

23 sintering temperature increase from $1000^{\circ} \mathrm{C}$ to $1550^{\circ} \mathrm{C}$, for the $\mathrm{PEG}$ derived powder

24 synthesized at $800^{\circ} \mathrm{C}$. For each of the samples, the relative density is greater than $98 \%$ 
1 of the theoretical density. Grain growth is negligible below $1200^{\circ} \mathrm{C}$, so that fully dense

$2 \mathrm{Y}_{2} \mathrm{O}_{3}$ ceramics can be obtained with a mean grain size of as low as $210 \mathrm{~nm}$ at $1000^{\circ} \mathrm{C}$.

3 For the commercial $\mathrm{Y}_{2} \mathrm{O}_{3}$ powder used in this study the required sintering temperature

4 was at least $1300^{\circ} \mathrm{C}$, and it was not possible, to obtain ceramics with a mean grain size

5 below $1 \mu \mathrm{m}$.

6

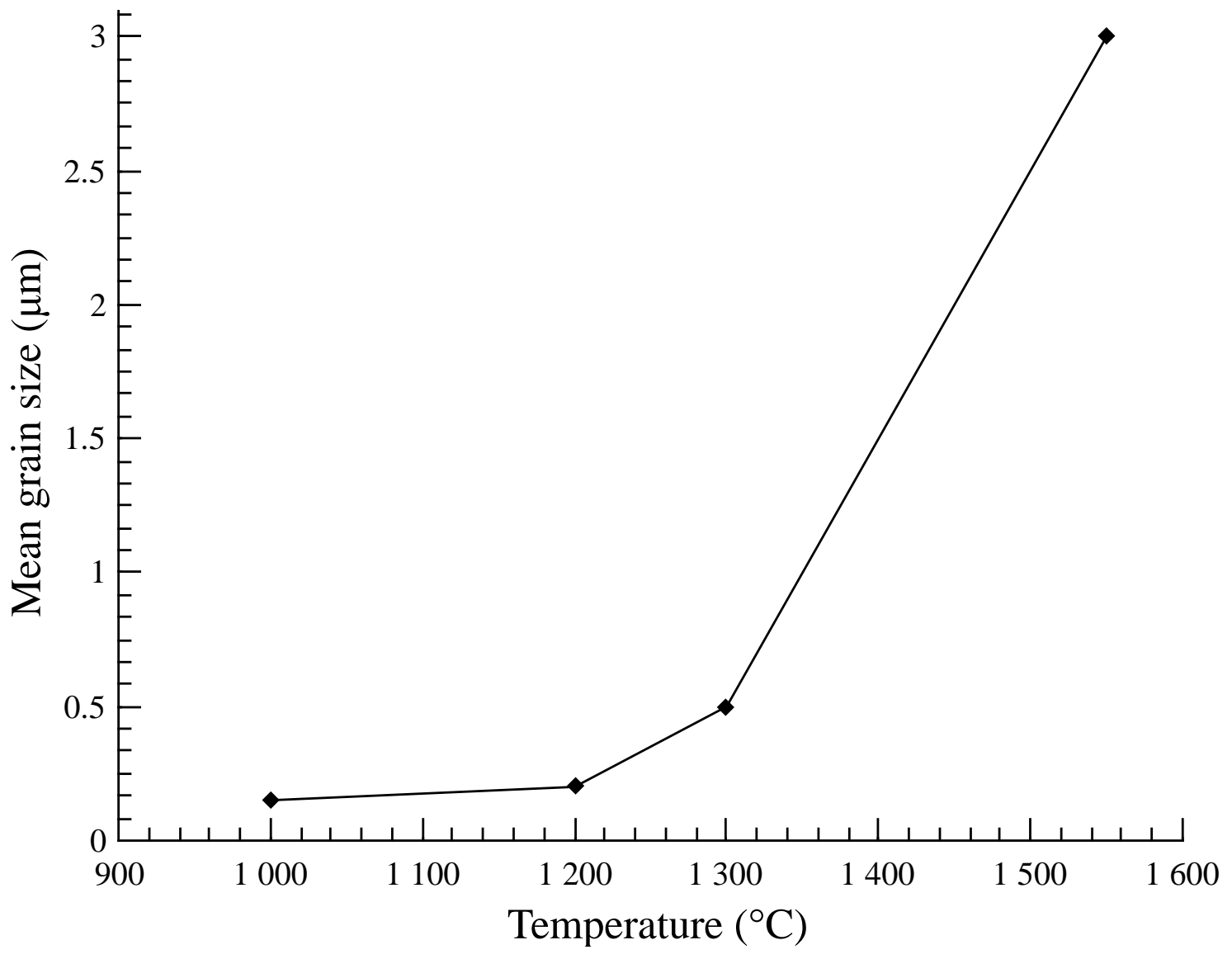

8 Figure 8. Mean grain size $v s$. sintering temperature for the ceramic samples made from

9 PEG derived powder synthesized at $800^{\circ} \mathrm{C}$ (dwell time: $1 \mathrm{~min}$, uniaxial pressure: 100

$10 \mathrm{MPa})$.

11

12 
1 Figure 9 shows the typical microstructure obtained after Spark Plasma Sintering of the

2 standard PEG derived $\mathrm{Y}_{2} \mathrm{O}_{3}$ nanopowder. The grain size distribution is homogeneous.

3 We also observed the presence of some residual porosity with a size in the range of 100

$4-400 \mathrm{~nm}$. This porosity is responsible for the opacity of all the ceramics samples, even

5 those with a very high relative density. The size of those pores is equivalent to the

6 macropore values observed in the starting nanopowders (see Figure 1). This suggests

7 that the opacity observed for all the ceramic samples stems from the macroporosity

8 formed during the calcination step of the precursor nanopowders. As previously

9 discussed, we expected that the macropores would be broken more easily during Spark

10 Plasma Sintering once the powder was annealed at a lower temperature. Thus we

11 annealed PEG derived $\mathrm{Y}_{2} \mathrm{O}_{3}$ powder at temperatures lower than $800{ }^{\circ} \mathrm{C}$ and selected

12 two powders for further Spark Plasma Sintering tests: one annealed at $450^{\circ} \mathrm{C}$ for 10

13 hours (sample $450^{\circ} \mathrm{C}-10 \mathrm{~h}$ ) and the other annealed at $650^{\circ} \mathrm{C}$ for $1 \mathrm{~h}$ (sample $650^{\circ} \mathrm{C}-1 \mathrm{~h}$ ).

14 The obtained results are presented in Figure 10. Note that in this graph, the shrinkage

15 observed below $400^{\circ} \mathrm{C}$ is mainly due to the application of uniaxial pressure. Beyond this

16 temperature, the pressure is maintained at $100 \mathrm{MPa}$.

17

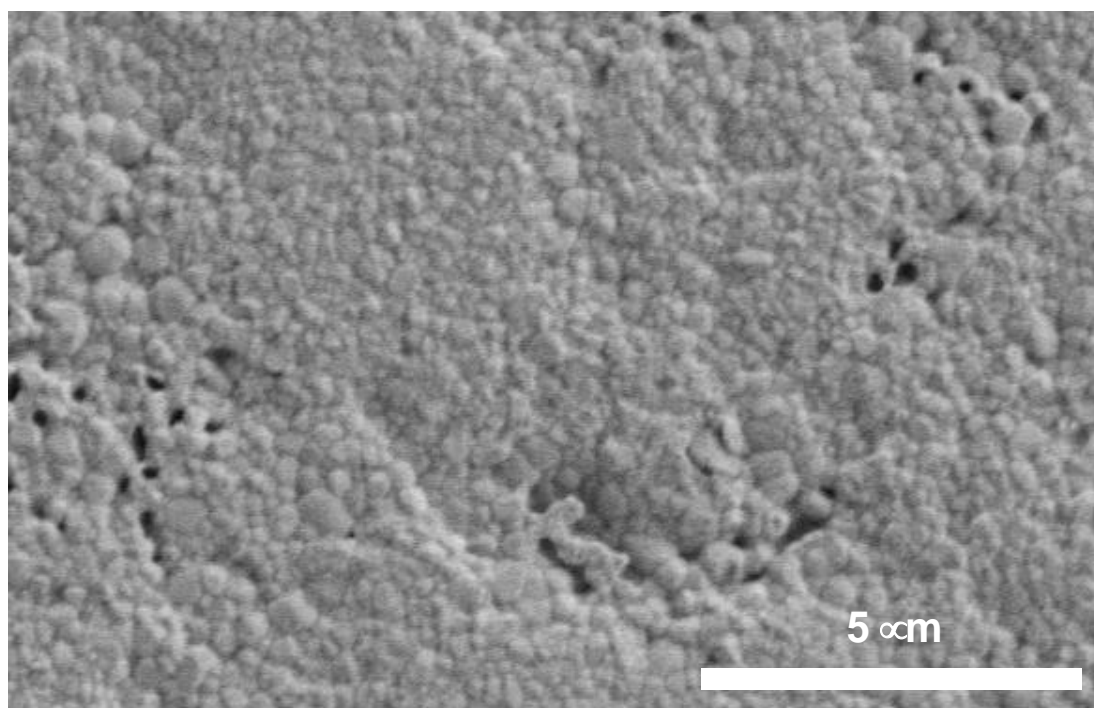


1 Figure 9. Microstructure of $\mathrm{Y}_{2} \mathrm{O}_{3}$ ceramics sintered by SPS at $1000^{\circ} \mathrm{C}-1$ min under 100

2 MPa uniaxial pressure from PEG-derived powder annealed at $800^{\circ} \mathrm{C}$.

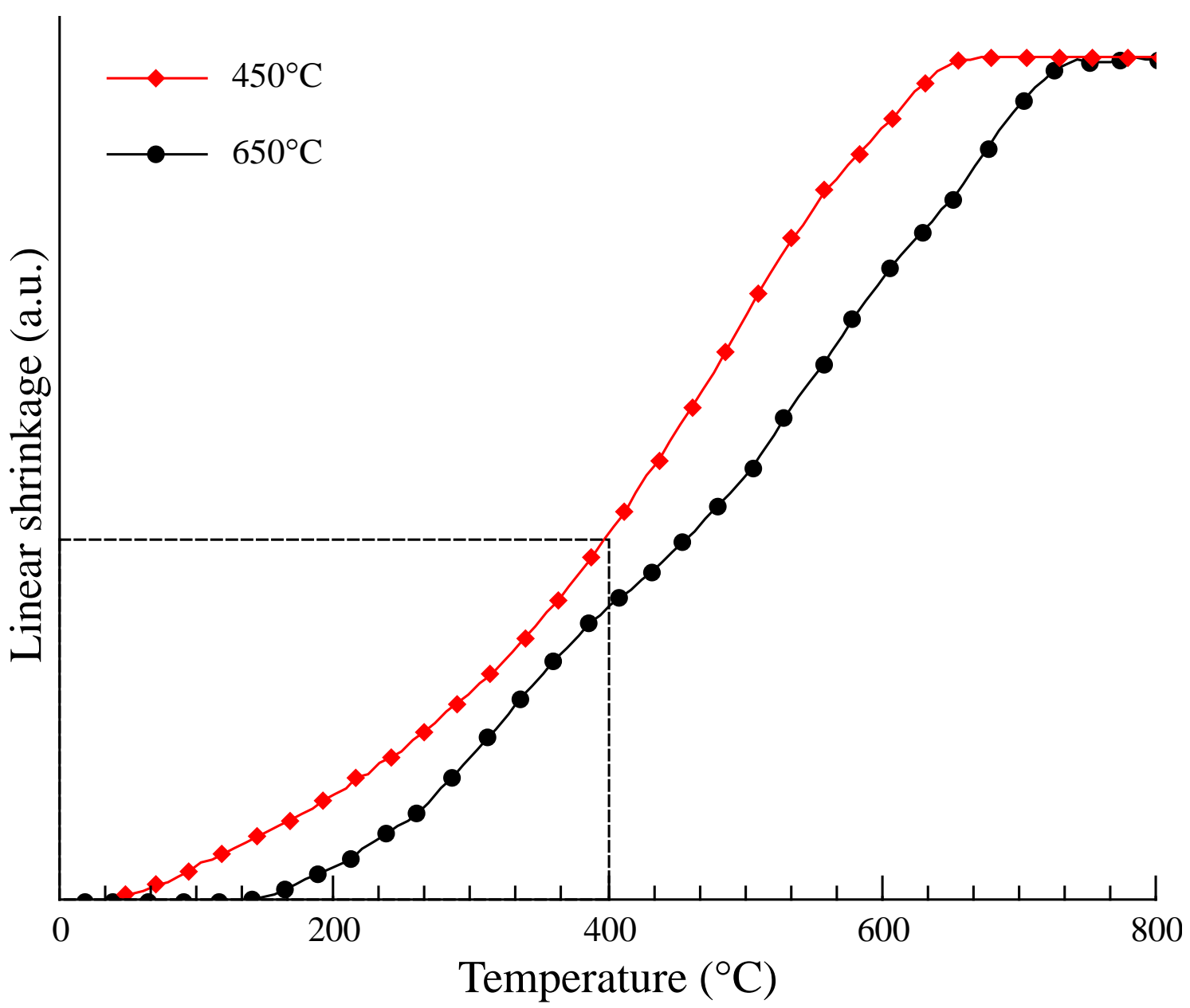

6 Figure 10. SPS linear shrinkage under $100 \mathrm{MPa}$ uniaxial pressure for samples made of

7 PEG derived powder annealed at $450^{\circ} \mathrm{C}-10 \mathrm{~h}$ (red lozenges) and $650^{\circ} \mathrm{C}$ (black circles).

9 As expected, the temperature of densification decreases as the annealing temperature of

10 the powder decreases. Thus, the densification of the ceramic sample prepared from the

11 powder annealed at $450^{\circ} \mathrm{C}-10 \mathrm{~h}$ is completed at $650^{\circ} \mathrm{C}$, while this process is prolonged

12 to about $750^{\circ} \mathrm{C}$ for the other sample (see Figure 10 ). Nevertheless, the maximum 
1 relative density of the ceramic obtained from the $450^{\circ} \mathrm{C}-10 \mathrm{~h}$ powder after sintering at

$21000^{\circ} \mathrm{C}$ is $95.5 \%$, whereas a ceramic sample with a relative density of $100 \%$ is

3 obtained under the same SPS conditions for the $650^{\circ} \mathrm{C}-1 \mathrm{~h}$ powder.

4 Figure 11 shows the typical microstructures obtained after Spark Plasma Sintering at

$51000^{\circ} \mathrm{C}$ of the powders previously annealed at $450^{\circ} \mathrm{C}-10 \mathrm{~h}$ and $650^{\circ} \mathrm{C}-1 \mathrm{~h}$. The mean

6 grain sizes are around $250 \mathrm{~nm}$ and $300 \mathrm{~nm}$, respectively. The ceramic sample made

7 from the powder annealed at $450^{\circ} \mathrm{C}-10 \mathrm{~h}$ exhibits residual porosity, unlike the other

8 ceramic sample $\left(650^{\circ} \mathrm{C}-1 \mathrm{~h}\right)$ which appears to be fully dense. The lower relative density

9 of the first sample is probably due to the release of the carbonate species for the powder

10 annealed at $450^{\circ} \mathrm{C}$ (see Figures 2 and 3). Since the sample made from the powder

11 annealed at $650^{\circ} \mathrm{C}$ is free of carbonate species, no porosity is formed around $650^{\circ} \mathrm{C}$

12 during the sintering step. Note that this sample is very slightly translucent, by contrast

13 with the one obtained from the powder annealed at $450^{\circ} \mathrm{C}-10 \mathrm{~h}$ (Figure 12). It is worth

14 noting that in those two samples, unlike in the ceramics made from the powder annealed

15 at $800^{\circ} \mathrm{C}$, no macropores could be observed in the microstructures, demonstrating that

16 reducing the annealing temperature of the $\mathrm{Y}_{2} \mathrm{O}_{3}$ precursor is actually a good way of

17 avoiding the emergence of macropores. However, the process optimization of different

18 steps of the ceramic fabrication (for example green body shaping and thermal profile

19 during SPS sintering and the subsequent annealing step) is needed in order to achieve

20 better optical characteristics in the studied ceramic samples. 

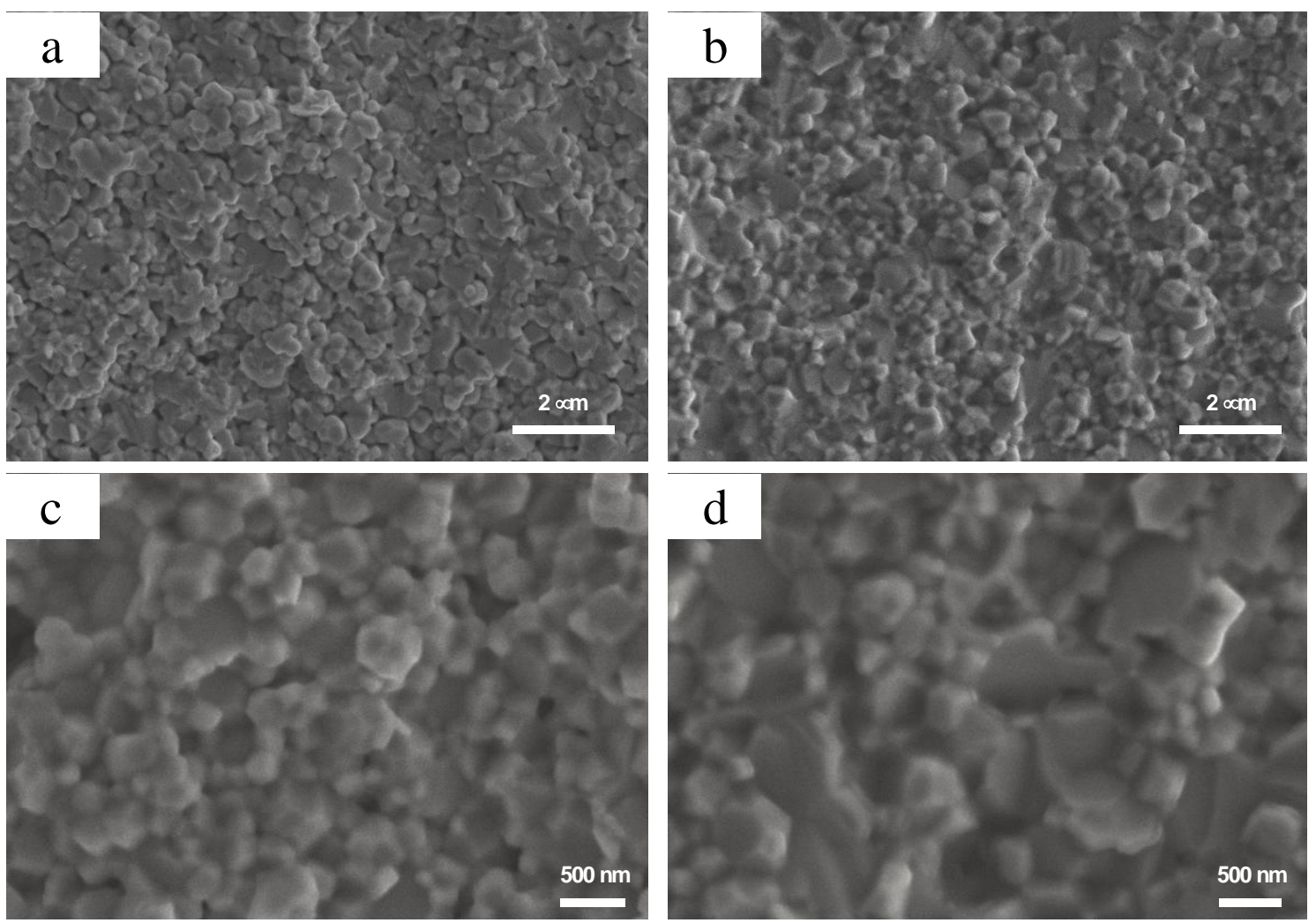

2 Figure 11. Typical microstructures of $\mathrm{Y}_{2} \mathrm{O}_{3}$ ceramics sintered at $1000^{\circ} \mathrm{C}$ from the PEG-

3 derived powder annealed at $450^{\circ} \mathrm{C}$ for 10 hours (a and c) and $650^{\circ} \mathrm{C}$ for 2 hours (b and 4 d). 


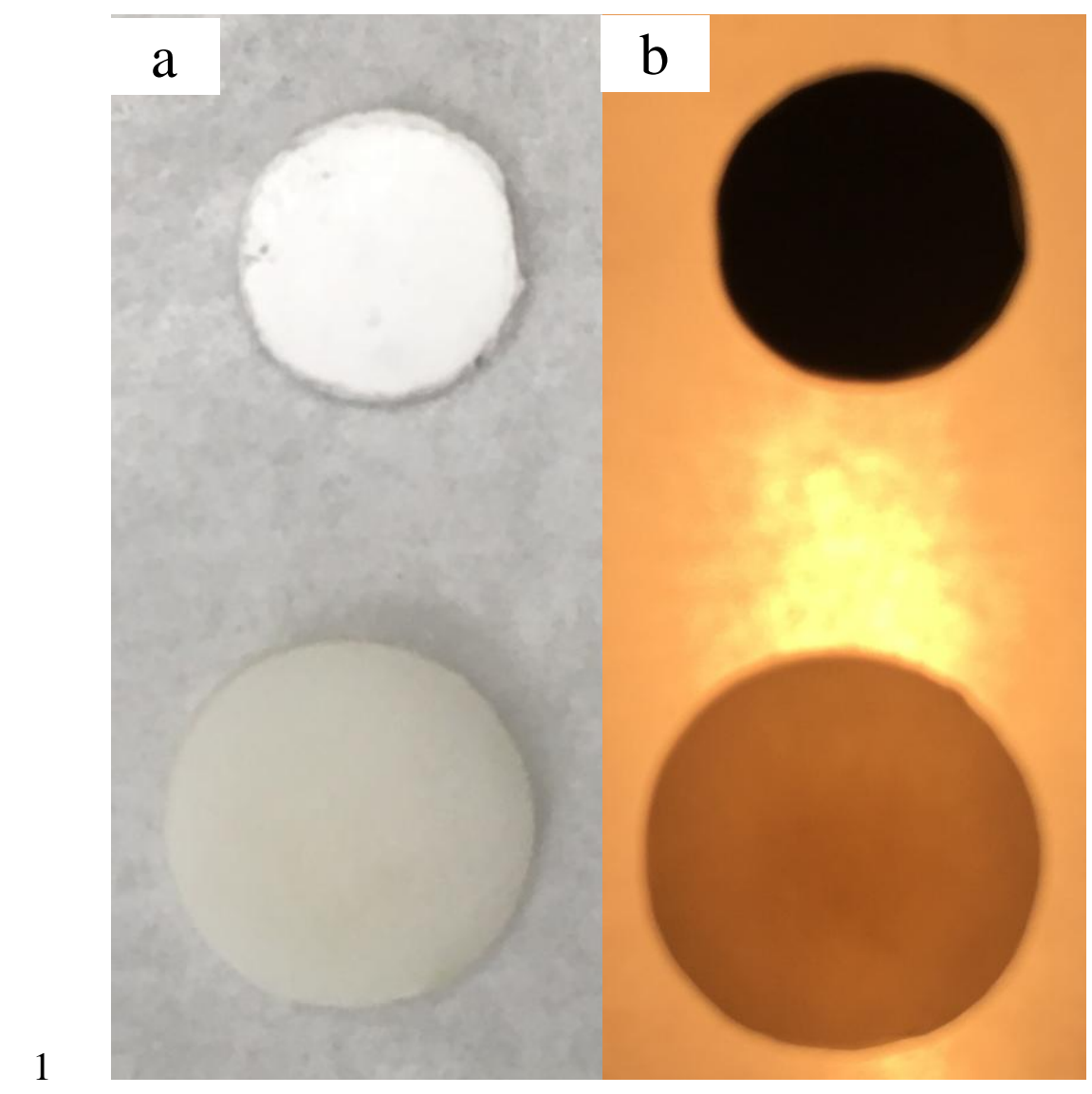

2 Figure 12. Ceramics made from the powder annealed at $450^{\circ} \mathrm{C}-10 \mathrm{~h}$ (upper) and $650^{\circ} \mathrm{C}$ -

3 1h (lower) placed on a light source, switched OFF (a) and ON (b).

4

5 Vickers microhardness and fracture toughness were measured on three $\mathrm{Y}_{2} \mathrm{O}_{3}$ ceramic

6 samples, all sintered at $1000^{\circ} \mathrm{C}$ for 1 min: one made from the raw commercial powder,

7 one made from the powder annealed at $650^{\circ} \mathrm{C}-1 \mathrm{~h}$, and one made from the powder

8 annealed at $450^{\circ} \mathrm{C}-10 \mathrm{~h}$. The results are summarized in Table 1.

9

10 Table 1. Vickers hardness $(\mathrm{Hv})$, fracture toughness $\left(\mathrm{K}_{\mathrm{IC}}\right)$, relative density and mean

11 grain size for selected $\mathrm{Y}_{2} \mathrm{O}_{3}$ ceramics samples.

\begin{tabular}{lllll}
\hline \multirow{2}{*}{ Sample } & $\mathrm{Hv}$ & $\mathrm{K}_{\mathrm{IC}}$ & Relative density & Mean grain size \\
& $(\mathrm{GPa})$ & $\left(\mathrm{MPa}^{1 / 2}\right)$ & $(\%)$ & $(\mu \mathrm{m})$ \\
\hline
\end{tabular}




\begin{tabular}{|c|c|c|c|c|}
\hline $\mathrm{Y}_{2} \mathrm{O}_{3}$ commercial & $6.8+/-0.1$ & $0.67+/-0.03$ & 99.0 & $1-3$ \\
\hline $\begin{array}{l}\mathrm{Y}_{2} \mathrm{O}_{3} \text { annealed at } \\
650^{\circ} \mathrm{C}-1 \mathrm{~h}\end{array}$ & $8.2+/-0.1$ & $0.90+/-0.1$ & 100 & 0.3 \\
\hline $\begin{array}{l}\mathrm{Y}_{2} \mathrm{O}_{3} \text { annealed at } \\
450^{\circ} \mathrm{C}-10 \mathrm{~h}\end{array}$ & $4.0+/-0.1$ & ND & 95.5 & 0.25 \\
\hline
\end{tabular}

1

2 The values of microhardness and fracture toughness are consistent with those found in

3 the literature [37,38]. As previously shown, the sample made from the powder annealed

4 at $450^{\circ} \mathrm{C}-10 \mathrm{~h}$ contains a substantial number of residual pores (see Figure 11a).

5 Consequently, the microhardness value is low and the fracture toughness is impossible

6 to measure to an acceptable accuracy. A typical indent with radial cracks is shown in

7 Figure 13. It is worth noting that the indent diagonal is in the range $25-40 \mu \mathrm{m}$, i.e.

8 more than 30 times longer than the mean grain diameter. This means that grain

9 boundaries have a strong effect on the value of microhardness and fracture toughness,

10 since grain boundaries stop the propagation of the dislocations and microcracks induced

11 by the application of the indenter on the surface [39]. As expected, for dense samples,

12 microhardness and fracture toughness increase as grain size decreases (see Table 1).

13 According to the literature, the microhardness and fracture toughness of $\mathrm{Y}_{2} \mathrm{O}_{3}$ ceramics

14 can be further improved through sintering additives, such as $\mathrm{La}_{2} \mathrm{O}_{3}$ or $\mathrm{ZrO}_{2}[38,40]$. 


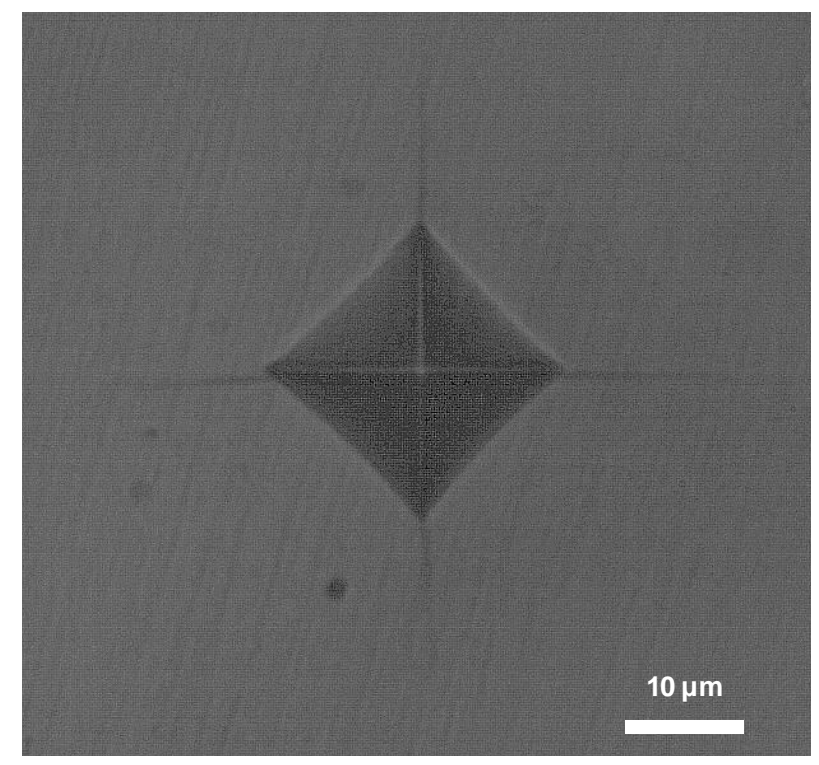

2 Figure 13. Optical micrograph of the indent in the sample made from the commercial

$3 \quad \mathrm{Y}_{2} \mathrm{O}_{3}$ and sintered by SPS at $1300^{\circ} \mathrm{C}-1 \mathrm{~min}$.

4

\section{4. Conclusions}

6 The polyethylene glycol (PEG) - assisted combustion method known as the polymer

7 complex solution (PCS) is a simple synthesis route that leads to a very reactive $\mathrm{Y}_{2} \mathrm{O}_{3}$

8 nanopowder which can be densified using the Spark Plasma Sintering technique

9 between $800^{\circ} \mathrm{C}$ and $900^{\circ} \mathrm{C}$ without any additive. This corresponds to one of the lowest

10 sintering temperatures found in the literature for $\mathrm{Y}_{2} \mathrm{O}_{3}$ ceramics.

11 Because of a significant release of organic species during synthesis and post-synthesis

12 thermal treatments, $\mathrm{Y}_{2} \mathrm{O}_{3}$ precursors obtained by the PCS route contain macropores that

13 have a negative impact on the final microstructure (meaning the presence of residual

14 porosity in the ceramic samples). Our results show that these macropores can be

15 minimized by decreasing the combusted and annealing temperature of the precursor.

16 Nevertheless, a minimum temperature of $650{ }^{\circ} \mathrm{C}$ is required in order to fully eliminate

17 the carbonate species. Finally, a precursor annealed at $650^{\circ} \mathrm{C}$ allows us to obtain a fully 
1 dense ceramic, with a very fine and homogeneous microstructure (and an average grain

2 size of around $300 \mathrm{~nm}$ ). Vickers microhardness and fracture toughness values were

3 found to be close to the values reported in the literature for undoped $\mathrm{Y}_{2} \mathrm{O}_{3}$ ceramics.

4 Because of the very good sinterability, the ceramic made from the PCS nanopowder

5 annealed at $650^{\circ} \mathrm{C}$ had a much smaller grain size and thus better mechanical properties

6 (a hardness of approximately 8.2 GPa and an appropriate fracture toughness of $0.9 \mathrm{MPa}$

$7 \mathrm{~m} 1 / 2)$ than the ceramics made from the micron-sized commercial $\mathrm{Y}_{2} \mathrm{O}_{3}$ powder $(\mathrm{a}$

8 hardness of approximately $6.8 \mathrm{GPa}$ and a fracture toughness of $0.67 \mathrm{MPa} \mathrm{m} 1 / 2$ ). We are

9 hopeful that the further optimization of the different steps in the ceramic fabrication

10 process (i.e. the shaping and subsequent Spark Plasma Sintering steps) will lead to fully

11 dense nanostructured ceramic materials with better optical and even better mechanical

12 properties, without the need for additives during sintering. In addition, given that

13 precursor morphological characteristics can be tailored by changing the temperature

14 needed to start the combustion process and for annealing, we believe that the findings

15 presented in this paper will be of use to many fellow researchers working on materials

16 produced by combustion synthesis or modifications of that process.

18 Acknowledgments

19 The authors are grateful to the trainee Johann Merlet for his enthusiastic participation in

20 the sintering experiments and Isabelle Genois for SEM and TEM observations at the

21 LCMCP laboratory. They also acknowledge Dr. Philippe Vermaut for indentation

22 experiments at Chimie ParisTech and Dr. Željka Antić from the Vinca Institute of

23 Nuclear Sciences for providing the standard PCS-produced $\mathrm{Y}_{2} \mathrm{O}_{3}$ powder $\left(800^{\circ} \mathrm{C}\right)$ and

24 its gel sample. R.K.W. acknowledges La Mairie de Paris for the award of a "Research in 
1 Paris" 2013-2014 fellowship, which enabled her stay at Chimie Paris Tech for the

2 realization of this research.

3

\section{References}

5 [1] L.B. Kong, Y.Z. Huang, W.X. Que, T.S. Zhang, S. Li, J. Zhang, Z.L. Dong, D.Y.

6 Tang, Transparent Ceramics, XII, Springer International Publishing AG, 2015.

7 [2] A. Fukabori, T. Yanagida, J. Pejchal, S. Maeo, Y. Yokota, A. Yoshikawa, T.

8 Ikegami, F. Moretti, K. Kamada, Optical and scintillation characteristics of $\mathrm{Y}_{2} \mathrm{O}_{3}$

9 transparent ceramic. J. Appl. Phys. 107 (2010) 073501.

10 [3] R.A. Lefever, J. Matsko, Transparent yttrium oxide ceramics, Mater. Res. Bull. 2

11 (1967) 865-869.

12 [4] S.R. Podowitz, R. Gaume, R.S. Feigelson, Effect of europium concentration on

13 densification of transparent $\mathrm{Eu}: \mathrm{Y}_{2} \mathrm{O}_{3}$ scintillator ceramics using hot pressing, J. Am.

14 Ceram. Soc. 93 (2010) 82-88.

15 [5] H. Eilers, Fabrication, optical transmittance, and hardness of IR-transparent

16 ceramics made from nanophase yttria. J. Eur. Ceram. Soc. 27 (2007) 4711-4717.

17 [6] J. Mouzon, A. Maitre, L. Frisk, N. Lehto, M. Odén, Fabrication of transparent yttria

18 by HIP and the glass-encapsulation method, J. Eur. Ceram. Soc. 29 (2009) 311-316.

19 [7] H. Mingsheng, L. Jianbao, L. Hong, G. Gangfeng, L. Long, Fabrication of

20 transparent polycrystalline yttria ceramics by combination of SPS and HIP, J. Rare

21 Earths 24 (2006) 222-224.

22 [8] Y.H. Huang, D.L. Jiang, J.X. Zhang, Q.L. Lin, Fabrication of transparent

23 lanthanum-doped yttria ceramics by combination of two-step sintering and vacuum

24 sintering, J. Am. Ceram. Soc. 92 (2009) 2883-2887. 
1 [9] L.L. Jin, G.H. Zhou, S. Shimai, J. Zhang, S.W. Wang, $\mathrm{ZrO}_{2}$-doped $\mathrm{Y}_{2} \mathrm{O}_{3}$ transparent

2 ceramics via slip casting and vacuum sintering, J. Eur. Ceram. Soc. 30 (2010) 2139-

32143.

4 [10] J.R. Groza, Nanosintering, Nanostructured Mater. 12 (1999) 987-992.

5 [11] J.P. Kelly, O.A. Graeve, Effect of powder characteristics on nanosintering, in:

6 R.H.R. Castro, K. van Benthem (Eds.), Sintering, Springer-Verlag, Berlin Heidelberg,

$7 \quad 2013$, pp. 57-95.

8 [12] I.W. Chen, X.H. Wang, Sintering dense nanocrystalline ceramics without final-

$9 \quad$ stage grain growth, Nature 404 (2000) 168-171.

10 [13] M.A.A. Attia, R. Orrù, F. Delogu, S. Montinaro, S. Garroni, E.M.M. Ewais, G.

11 Cao, Effects of prior annealing on the spark plasma sintering of nanostructured $\mathrm{Y}_{2} \mathrm{O}_{3}$

12 powders, J. Am. Ceram. Soc. 98 (2015) 1453-1459.

13 [14] O. Tokariev, L. Schnetter, T. Beck, J. Malzbender, Grain size effect on the

14 mechanical properties of transparent spinel ceramics, J. Eur. Ceram. Soc. 33 (2013)

$15 \quad 749-757$.

16 [15] R. Chaim, R. Marder, C. Estournes, Optically transparent ceramics by spark

17 plasma sintering of oxide nanoparticles, Scripta Mater. 63 (2010) 211-214.

18 [16] R. Chaim, A. Shlayer, C. Estournes, Densification of nanocrystalline Y2O3

19 ceramic powder by spark plasma sintering, J. Eur. Ceram. Soc. 29 (2009) 91-98.

20 [17] Y. Futami, T. Yanagida, Y. Fujimoto, J. Pejchal, M. Sugiyama, S. Kurosawa, Y.

21 Yokota, A. Ito, A. Yoshikawa, T. Goto, Optical and scintillation properties of $\mathrm{Sc}_{2} \mathrm{O}_{3}$,

$22 \mathrm{Y}_{2} \mathrm{O}_{3}$ and $\mathrm{Lu}_{2} \mathrm{O}_{3}$ transparent ceramics synthesized by SPS method, Radiat. Meas. 55

23 (2013) 136-140. 
1 [18] R. Chaim, R. Marder, C. Estournés, Z. Shen, Densification and preservation of

2 ceramic nanocrystalline character by spark plasma sintering, Adv. Appl. Ceram. 111

3 (2012) 280-285.

4 [19] J. Liu, Z. Shen, M. Nygren, B. Su, T.W. Button, Spark plasma sintering behavior

5 of nano-sized $(\mathrm{Ba}, \mathrm{Sr}) \mathrm{TiO}_{3}$ powders: determination of sintering parameters yielding

6 nanostructured ceramics, J. Am. Ceram. Soc. 9 (2006) 2689-2694.

7 [20] M. Eriksson, Y. Liu, J. Hu, L. Gao, M. Nygren, Z. Shen, Transparent

8 hydroxyapatite ceramics with nanograin structure prepared by high pressure spark

9 plasma sintering at the minimized sintering temperature, J. Eur. Ceram. Soc. 31 (2011)

$10 \quad 1533-1540$.

11 [21] H. Yoshida, K. Morita, B.N. Kim, K. Hiraga, M. Kodo, K. Soga, T. Yamamoto,

12 Densification of nanocrystalline yttria by low temperature spark plasma sintering, J.

13 Am. Ceram. Soc. 91 (2008) 1707-1710.

14 [22] L. An, A. Ito, T. Goto, Transparent yttria produced by spark plasma sintering at

15 moderate temperature and pressure profiles, J. Eur. Ceram. Soc. 32 (2012) 1035-1040.

16 [23] N. Poirot, D. Bregiroux, P. Boy, C. Autret-Lambert, P. Belleville, L. Bianchi,

17 Sintering of nanostructured $\mathrm{Sc}_{2} \mathrm{O}_{3}$ ceramics from sol-gel-derived nanoparticles, Ceram.

$18 \quad$ Int. $41(2015)$ 3879-3887.

19 [24] M. Hajizadeh-Oghaz, R. Shoja Razavi, M. Bareka, M. Naderi, S. Malekzadeh, M.

20 Rezazadeh, Synthesis and characterization of $\mathrm{Y}_{2} \mathrm{O}_{3}$ nanoparticles by sol-gel process for

21 transparent ceramics applications, J. Sol-Gel Sci. Technol. 78 (2016) 682-691.

22 [25] M. Khajelakzay, R.S. Razavi, M. Barekat, M. Naderi, Synthesis of Yttria

23 Nanopowders by Two Precipitation Methods and Investigation of Synthesis Conditions,

24 Int. J. Appl. Ceram. Technol. 13 (2016) 209-218. 
1 [26] R. Krsmanović, Ž. Antić, B. Bártová, M.D. Dramićanin, Characterization of rare-

2 earth doped $\mathrm{Lu}_{2} \mathrm{O}_{3}$ nanopowders prepared with polymer complex solution synthesis, J.

3 Alloys Compd. 505 (2010) 224-228.

4 [27] Ž. Antić, R. Krsmanović, M. Wojtowicz, E. Zych, B. Bártová, M.D. Dramićanin,

5 Preparation, structural and spectroscopic studies of $\left(\mathrm{Y}_{\mathrm{x}} \mathrm{Lu}_{1-\mathrm{x}}\right)_{2} \mathrm{O}_{3}: \mathrm{Eu}^{3+}$ nanopowders,

6 Opt. Mater. 32 (2010) 1612-1617.

7 [28] R.M. Krsmanović, Ž. Antić, M.G. Nikolić, M. Mitrić, M.D. Dramićanin,

8 Preparation of $\mathrm{Y}_{2} \mathrm{O}_{3}: \mathrm{Eu}^{3+}$ nanopowders via polymer complex solution method and

9 luminescence properties of the sintered ceramics, Ceram. Int. 37 (2011) 525-531.

10 [29] R.M. Krsmanović, Ž. Antić, B. Bártová, M.G. Brik, M.D. Dramićanin, Fabrication

11 of polycrystalline $\left(\mathrm{Y}_{0.7} \mathrm{Gd}_{0.3}\right)_{2} \mathrm{O}_{3}: \mathrm{Eu}^{3+}$ ceramics: the influence of initial pressure and

12 sintering temperature on its morphology and photoluminescence activity, Ceram. Int. 38

13 (2012) 1303-1313.

14 [30] R. Krsmanović Whiffen, Ž. Antić, B. Milićević, M. Pošarac-Marković, Dj.

15 Janaćković, M. D. Dramićanin, M. G. Brik, I. Steins, Dj. Veljović, Polycrystalline

$16\left(\mathrm{Y}_{0.7} \mathrm{Gd}_{0.3}\right)_{2} \mathrm{O}_{3}: \mathrm{Eu}^{3+}$ ceramics fabricated by spark plasma sintering: Densification and

17 microstructure development, Ceram. Int. 40 (2014) 8853-8862.

18 [31] L. Smrcok, Rietveld Refinement of $\mathrm{Y}_{2} \mathrm{O}_{3}$ using the Pearson VII Profile Shape

19 Function, Crystal Res. Tech. 24 (1989) 607-611.

20 [32] G.R. Anstis, P. Chantikul, B.R. Lawn, D.B. Marshall, A critical-evaluation of

21 indentation techniques for measuring fracture toughness. 1. Direct cracks

22 measurements, J. Am. Ceram. Soc. 64 (1981) 533-538.

23 [33] O. Yeheskel, O. Tevet, Elastic moduli of transparent yttria, J. Am. Ceram. Soc. 82

24 (1999) 136-144. 
1 [34] J.M. Luiz, J.R. Matos, I. Giolito, M. Ionashiro, Thermal behaviour of the basic

2 carbonates of lanthanum- europium, Thermochim. Acta 254 (1995) 209-218.

3 [35] E. Irom, M. Zakeri, A.S. Ahangari, H. Zadeh, S. Safian, A. Rahbari, Low-pressure

4 fabrication of IR-transparent $\mathrm{Y}_{2} \mathrm{O}_{3}$ via spark plasma sintering, Micro Nano Lett. 11

5 (2016) 688-691.

6 [36] H. Zhang, B.N. Kim, K. Morita, Y. Hidehiro, K. Hiraga, Y. Sakka, Fabrication of

7 transparent yttria by high-pressure spark plasma sintering, J. Am. Ceram. Soc. 94

$8 \quad$ (2011) 3206-3210.

9 [37] K. Serivalsatit, B. Kokuoz, B. Yazgan-Kokuoz, M. Kennedy, J. Ballato, Synthesis,

10 processing, and properties of submicrometer-grained highly transparent yttria ceramics,

11 J. Am. Ceram. Soc. 93 (2010) 1320-1325.

12 [38] K. Ning, J. Wang, D. Luo, J. Ma, J. Zhang, Z.L. Dong, L.B. Kong, D. Y. Tang,

13 Fabrication and characterization of highly transparent $\mathrm{Yb}^{3+}: \mathrm{Y}_{2} \mathrm{O}_{3}$ ceramics, Opt. Mater.

$1450(2015) 21-24$.

15 [39] I.J. McColm, Ceramic Hardness, Plenum Press, New York, 1990.

16 [40] L. Zhang, J. Feng, W. Pan, Vacuum sintering of transparent $\mathrm{Cr}: \mathrm{Y}_{2} \mathrm{O}_{3}$ ceramics,

17 Ceram. Int. 41 (2015) 8755-8760. 